\title{
Steady State Total Body Clearance by Fraction of Dose Absorbed
}

National Cancer Institute

\section{Source}

National Cancer Institute. Steady State Total Body Clearance by Fraction of Dose

Absorbed. NCI Thesaurus. Code C85814.

An estimate of the total body clearance at steady state, where $F$ is the fraction of dose absorbed. 